\title{
Guillaume de Machaut, Quatre dits
}

\section{G. Matteo Roccati}

\section{(2) OpenEdition}

\section{Journals}

\section{Édition électronique}

URL : http://journals.openedition.org/studifrancesi/6535

DOI : 10.4000/studifrancesi.6535

ISSN : 2427-5856

\section{Éditeur}

Rosenberg \& Sellier

\section{Édition imprimée}

Date de publication : 1 septembre 2010

Pagination : 334-335

ISSN : 0039-2944

\section{Référence électronique}

G. Matteo Roccati, «Guillaume de Machaut, Quatre dits », Studi Francesi [En ligne], 161 (LIV | II) | 2010 mis en ligne le 30 novembre 2015, consulté le 08 janvier 2021. URL : http://journals.openedition.org/ studifrancesi/6535; DOI : https://doi.org/10.4000/studifrancesi.6535

Ce document a été généré automatiquement le 8 janvier 2021.

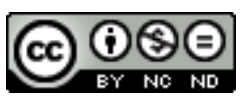

Studi Francesi è distribuita con Licenza Creative Commons Attribuzione - Non commerciale - Non opere derivate 4.0 Internazionale. 


\title{
Guillaume de Machaut, Quatre dits
}

\author{
G. Matteo Roccati
}

\section{RÉFÉRENCE}

GUILLAUME DE MACHAUT, Quatre dits, Traduits et annotés par Isabelle BÉTEMPS, Paris, Champion, 2008 («Traductions des classiques du Moyen Âge», 82), pp. 202.

1 On trouvera dans ce volume la traduction de quatre dits - Dit de la Marguerite, Dit de la Rose, Dit de la Fleur de Lis et de la Marguerite et Dit du Cerf Blanc-, traduction établie d'après l'éd. Fourrier (Droz, 1979) et enrichie de notes. Tous sont assez courts (respectivement 208, 106, 416 et 863 vers) et appartiennent à la dernière période de la production de Machaut.

2 L'introduction présente rapidement la vie et les œuvres du poète, propose ensuite une analyse de la forme et du contenu des quatre œuvres, quelques réflexions sur le "genre" du dit et sa concrétisation dans ces textes, sur leur caractère courtois et l'art d'aimer qui s'y exprime, sur la référence au Roman de la rose et sur les thèmes de la clarté et des couleurs. Le volume comporte également une bibliographie (pp. 87-101) et un Index des noms propres et des notions (pp. 199-200). 